\title{
ӘӨЖ 82
}

Шұға АКАТАЕВА, ф.в.к., доиент, Қазтұтынуодавы Қараванды университеті, 100009, Қазақ̆стан Республикасы, Қаразанды құаласы, Академическая көш.9., akataeva_shuga@mail.ru,+7017507369

Ләйлә АКШАБАЕВА, педагогика выльидарының магистрі, Қазтұтынуодагы Қараванды университеті, 100009, Қазақ̧стан Республикасы, Қараванды қ̧аласы, Академическая көш.9., leila.aks@mail.ru,+7771084310

\section{ЖАЗБА ЕСКЕРТКІШТЕР ТІЛІНДЕГІ ЛЕКСИКА-СЕМАНТИКАЛЫҚ ЕРЕКШЕЛІКТЕР}

Мақалада XV-XVII ғасырлардағы ескі қазақ жазба тілі үлгілеріндегі көне түркілік лексика қабаты, ескі қазақ жазба ескерткіштер тілінде кездесетін араб және парсы негізді лексика құрамын зерттеу мәселесі қарастырылды.XVII ғасырдың басында жазылған Қадырғали Жалайыридің «Жамиғат-Тауарих» шежіресі, Әбілғазының «Түркі шежіресі» шығармалары лексика-семантикалық ерекшеліктерге талданады.

Түйінді сөздер: Жазба ескерткіштер, көне түркі сөздер, Түркі шежіресі, Жамиғат Тауарих.

Шуга АКАТАЕВА, кандидат филологических наук, доцент, Карагандинский университет Казпотребсоюза, 100009, Республика Казахстан, г.Караганда, ул.Академическая 9., akataeva_shuga@mail.ru,+7017507369

Лейла АКШАБАЕВА, магистр педогогических наук, Карагандинский университет Казпотребсоюза, 100009, Республика Казахстан, г.Караганда, ул.Академическая 9., leila.aks@mail.ru, +7771084310

\section{ЛЕКСИКО-СЕМАНТИЧЕСКИЕ ОСОБЕННОСТИ ЯЗЫКА ПИСЬМЕННЫХ ПАМЯТНИКОВ}

В статье рассмотрена проблема изучения древнетюркского лексического слоя в образцах древнеказахского письменного языка XV-XVII веков, арабского и персидского основных лексических составов, встречающихся в древнеказахском языке письменных памятников. Анализируются лексикосемантические особенности летописи Кадыргали Жалаири «Жамигат-Тауарих», «Түркі шежіресі» Абылгази, написанная в начале XVIII века.

Ключевые слова: письменные памятники, древнетюркские слова, Тюркская шежире, Жамигат Тауарих.

ShugaAKATAYEVA, Candidate of Philological Sciences, Associate Professor, Karaganda University of Kazpotrebsoyuz, 100009, Republic of Kazakhstan, Karaganda, Akademicheskaya str. 9., akataeva_shuga@mail.ru,+7017507369

Leyla AKSHABAYEVA, Master of Pedagogical Sciences, Karaganda University of Kazpotrebsoyuz, 100009, Republic of Kazakhstan, Karaganda, Akademicheskaya str.9., leila.aks@mail.ru, +7771084310

\section{LEXICO-SEMANTIC FEATURES OF THE LANGUAGE OF WRITTEN MONUMENTS}

The article deals with the problem of studying the ancient Turkic lexical layer in the samples of the ancient Kazakh written language of the XV-XVII centuries, Arabic and Persian, the main lexical compositions found in the Ancient Kazakh language of written monuments. The article analyzes the lexical and semantic features of the annals of Kadyrgali Zhalairi "Zhamigat-Tauarikh", "Turkishezhiresi" of Abylgazi, written at the beginning of the XVIII century.

Keywords: written monuments, ancient Turkic words, Turkic shezhire, Zhamigat Tauarikh. 
Түркі жазба ескерткіштерінің лексикографиясы сөз болғанда, ондағы сөздердің мынаусы қыпшақ тілінің, мынаусы оғыз тілінің, қайсыбірі қарлұқ тілінің сөздері деп бөлу тым шартты, өйткені бұлай бөлуде негізге алатын критериіміз - белгілі бір сөздің қазір қай тілде байырғы өз мағынасы мен тұлғасын өзгертпей сақтауы. XV-XVII ғасырлардағы жазба ескерткіштердің ішінде Әбілғазы шежіресі жазылған түркі халықтарының қазіргідей шекаралары белгіленіп, өз алдына жеке ел болып бөлінбегенін, бөлінсе де, өзара аралас-құралас көшіп жүргенін, біресе ана хандықтың, біресе мына хандықтың қол астына қарап өмір сүргенін ескермеске болмайды. Оның үстіне шығарма авторының өскен, кейін хандық құрған Хорезм аймағындағы оның араласқан халқының құрамы - өзбек, түрікмен, ұйғыр, қазақ рулары (арғын, найман, қыпшақ, қоңыраттар) болғанын «Шежіре» мәтінінен айқын көруге болады. Мәселен, Әбілғазының айтуына қарағанда, XVII ғасырдың орта тұсында түрікмендер үшке бөлініп, үш жерді мекендеген: Маңқышлақ, Абдуллахан тауы және Тежен суының жағасы. Әбілғазы хандық басына келер кезде Хорезмдегі барлық түрікмендер одан қорқып, жоғарыдағы үш жұртқа үдере көшкен. Одан біраз жыл өткенде олардың бірқатары күшпен, бірқатары өз еріктерімен Хорезм аймағына қайта жиналған. Тіпті Әбілғазының өзі сүйенген өзбектері қазіргі өзбек аталып кеткен халық не ұлт емес, бір кезде Өзбек ханның қол астында қыпшақ даласында өмір сүрген, кейін Алтын Орданың ыдырауымен байланысты ығысып, Орта Азияға ауысқан түркі тайпаларының өкілдері, яғни көшпелі өзбек аталған рулар еді. Олардың негізгі бөлігі қыпшақ рулары екендігіне күмән келтірмейді. Сондықтан Әбілғазы шығармасының тілі қыпшақ негіздегі тіл екендігі, оның қазақ тіліне тым жақындығы да содан болса керек.

Ал XVII ғасырдың басында жазылған Қадырғали Жалайыридің «Жамиғат-Тауарих»атты шежіресінің тілін сөз еткен Р.Ғ.Сыздықова «оның лексикасының түрік бөлігінде қыпшақ тілі сөздері белгілі орын алды», - деп жазады $[1,27]$. Ал негізін қыпшақ тілі құрайтын Әбілғазының «Түркі Шежіресінде» көне түркі сөздерді едәуір орын алады. Оның басты себебі, «Шежіреде» автордың өз шығармасын сол кезеңде ұлт болмаса да, жеке халық болып жіктеле бастаған өзбек, түрікмен не қазақ тілінде жаздым демей, бәріне ортақ түрік тілінде жаздым деуінен аңғаруға болады.

«Түркі Шежіресінде» кездесетін көне түркі сөздері біршама. Олардың бір ерекшелігі Әбілғазы тұсында қолданылған өзіндік тілдік варианттарымен қатарласа жүруі. Мысалы, шежіреде «жазу» мағынасында біті сөзі кездеседі, мыс.: Барча түркілернің ұрығын бірін қоймай бітімек уа айтмақ бір кішінің қолындын келмес; Бізде мұғұл тілі бірлән бітілген кітаблар бар бітілмеген сөзлеріні йад біле тұрған кішілеріміз бар... (Барлық түркі руының бірін қалдырмай жазу және айту бір кісінің қолынан келмейді. Бізде моңғол тілінде жазылған кітаптар бар, жазылмаған сөздерді жадында сақтайтын кісілеріміз де бар...) [2, 62].

Екінші бір жерде бұл сөздің кейінгі дәуірге тән варианты - жазу сөзі де кездеседі. Қадырғалидің «Жамиғат-Тауарихында» да йаз, біті сөздері қатар қолданылады. Мысалы: Біз аның барчасыны хатқа йазсақ сөз ұзақ боладұр... (Біз оның барлығын хатқа жазар болсақ, сөз (әңгіме) ұзақ болады...) [3, 250].

Алайда йаз сөзіне қарағанда, біті сөзі көбірек қолданылған. Осындай көне сөздердің бірі қазіргі «халық» мағынасындағы бұдұн сөзі. Мысалы: Аның үчүн бұдұн мүлкінің падшаһы йүрек тұрұр... (Оның үшін халық мүлкінің патшасы - жүрек...) [2, 62].

Бірақ бұл сөз көп кездеспейді, оның орнына халық сөзі жиі қолданылған, мысалы: Ұғылы Алынча ханны йерінде қойұб халық бара тұрған йерге барды//Нече йылдын бері [халқның тұзын йеб йүрүрмін... (Ұлы (баласы) Алынча ханды тиісті жеріне апарып, халық баратын жерге барды//қаншама жылдан бері халықтың тұзын (ақысын, еңбегін) жеп келемін...) [2, 62]. «Түркі Шежіресінде» осы сияқты «жәй қара халық, жұрт» мағынасында қарайман сөзі де ұшырайды, мысалы: Қарайманның йылқыдын сығырдын не өзкелікі бар...(Қара халықтың жылқы мен сиырдан не айырмашылығы бар.) [2, 63].

Бұдын сөзі Орхон-Енисей жазбаларынан бастап орта ғасырдағы ескі қыпшақ ескерткіштеріне дейін халық сөзімен қатарласа қолданылғаны белгілі. Ал «Тауарихта» осы мағынаны беретін улус сөзі термин ретінде қолданылады, мыс.: Ойда орус қырда татар барча улусны бақтұрған хан... (Ойда (сайда) орыс, қырда татар, барлық халықты бағындырған хан...) [3, 141].

Сонымен қатар, бұл сөз «мемлекет» мағынасында да қолданылған, мысалы: Барча улус ічінде Мәскеу атлығ шаһарың душмандарға көп дүр... (Барлық мемлекеттердің ішінде Мәскеу деп аталатын қалаңның дұшпаны көп...) [3, 142]. «Түркі Шежіресіндегі» көне тұлғаның бірі - ау сөзі. Бұл сөз Орхон ескерткіштерінде аб формасында келсе, көне қыпшақ жазбаларында ав тұлғасында келеді. Ал «Түркі Шежіресінде» ау түрінде кездеседі, мыс.: Күнлерде бір күн ауға чықыб киік өлтүрүб кабаб қылыб аны йеділер... Атсыз хан ата орныда олтұрұб бір нече 
йыллар йауыны йаулаб ауыны аулаб атасы кейініден кетді... Барчасы аучы болұрлар кіш уа сусар уа ас уа тиын уа құндұз суда балық қырда киік жанлы нәмерсе барчасыны ауларлар... (Күндердің бір күнінде аңға шығып киік аулап, оны кәуап (отқа қақталған ет) қылып жеді... Атсыз хан атасының орнына отырып, бірнеше жылдар бойы жауын жаулап, аңын аулап атасының соңынан кетті (жолын қуды)... Барлығы аңшы еді, кіш (аң түрі), сусар, ас (аң түрі), тиын, құндыз, суда балық, қырда киік, жанды не болса, барлығын аулады...) [2, 62].

Ортағасырларда жазылған өзге көптеген тарихи шығармалармен салыстырғанда, мұндағы түркі сөздері қыпшақтық тұлғада берілген. «Тауарихта» «аң аулау» мағынасында аң, аңға чық, аңға атлан сияқты сөз тіркестері берілген, мысалы: Оғуз нөкерлері білән ба'зи дост лары білән йазыда аңға чықыб ерді... (Жазда Оғыз нөкерлері (көмекшілері) және ескі достарымен аңға шығып еді...) $[5,151]$.

«Шыңғыснамада» Шыңғыс хан туралы дастанында Жошының аңға шыққандығын айта келе, ав авла тіркесін қолданылған, мысалы: Йочы хан бір күн тағ арасындә ав авлайы чықыб ерді... (Бір күні Жошы хан тау арасына аңға шығып еді...) [3, 120].

«Әділ сұлтан» эпикалық жырында $c y$ сөзі қазіргі қазақ тіліндегідей қолданылған: ...судай толқытып омрауын салқытып исі жұфар аңқытып... (...судай толқытып, омырауын салқытып, иісін жұпар аңқытып...) [6, 61].

«Түркі Шежіресінде» «жиылған әскер» мағынасында аламан сөзі кездеседі, мысалы: Кетмей тұр текен йерде бір аламан йоқ аламанның барчасы олжасы бірлән йығылыб тұрұр...(Кетпей тұр деген жерде бір аламан жоқ, аламанның барлығы олжаларымен жиналып тұр...) [2, 63]. Бұл сөзді XV-XVIII ғасырлардағы ауыз әдебиеті нұсқаларынан да кездестіреміз. «Түркі Шежіресінде» аламан сөзіне мағыналас нөкер, черік, ләшкер сөздері де кездеседі. «Тауарихта» да ләшкер және нөкер [4, 361] сөздері кездеседі, мысалы: Аның соңғудан Оң хан білән оғлы Сәнгүн бір болуб, ләшкер тартыб на каһ Чингиз ханның үстіне барғай лар. Оғуз нөкерлері білән ба'зи дост лары білән йазыда аңға чықыб ерді... (Оның соңынан Оң хан мен ұлы Сәнгун бірігіп, әскер тартып нақ Шыңғыс ханның үстіне барады. Жазда Оғыз нөкерлері (көмекшілері) және ескі достарымен аңға шығып еді...) [6, 173].

«Шыңғыснамада» ләшкәр, нөкер және чәрік сөздері қатар қолданылған, мыс.: ...'әзім ләшкәр қошуб Дәшті Қыпчақ уілайатынға салғап йібәрді... (...көп аламан қосып тура Дешт-и Қыпшақ еліне кетті...) [3, 120]; Сайын хан Іділ дариясы бойнынға келгәч чәрік йарағын қылыб Ұрұс вілайатының шәһрі Мәскәугә йүріді... (Сайын хан Еділ дариясы бойына келгенше әскер жарақтанып, Орыс елінің Мәскеу қаласына аттанды...) [3, 122].

Бірақ «Әділ сұлтан» эпикалық жырында ләшкер сөзі кездеспейді.

«Түркі Шежіресінде» кездесетін қызмет түрін білдіретін боқауыл «ханның ас-суын басқарушы», ереуіл «шабуылда жекпе-жекке шығушы», йортағұл «ел шауып келуші», қарауыл «қорғаушы, оққағар», чапұғұл «шабуылшы», сұрауыл «жау жақтан хабар әкелуші» тәрізді бірнеше сөздер бар. Бұлардың көпшілігі қазір көнерген сөздер қатарына жатады, ал Әбілғазы заманында қолданыста болғаны байқалады. Қарауыл сөзі «Шыңғыснамада» да қолданылған, мысалы: ...отыз мың кіші қошуб қарауыл йібәрді... (...отыз кісі қосып, қорғаушыны жіберді...) [3, 122].

«Түркі Шежіресінде» кездесетін бірсыпыра көне түркі тілі сөздерінің мағынасы өзгеріске ұшыраған, қазіргі қазақ тілінде басқа мағынада қолданылады. Мәселен, арқа сөзі шежіреде «ұрпақ» мағынасында келеді. Мысалы: Бізнің ұлұғ атамыз һалаку хан Мұғұлстандын келгенден бері екі үч арқа өтді... Тоқыз арқа болғұнча шондағ болғай... (Біздің үлкен атамыз (бабамыз) һалаку хан Моңғолстаннан келгеннен бері екі-үш ұрпақ өтті... Тоғыз ұрпақ болғанша солай болады...) [5, 64]. Сонымен бірге бұл сөзден жасалған қазіргі «арқа сүйеді» мағынасында арқа берді деген фразеологизм де кездеседі, мыс.: Біздей бөлек бөлек йасамады пиада түшмеді көблікіне арқа берді... (Біз секілді бөлек бөлек жасамады, жаяу жүрмей көптігіне сүйенді...) [2, 64].

Қазіргі әдеби тілімізде «қарындас» сөзі ер адам тарапынан өзінен жасы кіші қыз балаға айтылады, ал «Түркі Шежіресінде» қарындаш сөзі «ағайын, тума» деген бұдан кең мағынада қолданылған, мыс.: Хамар текен Хорезм шаһының анасы Тұрқан хатұнның қарындашы ерді аны Үркенічде хәкім қылыб ерді... Екісінің бір біріне һеч қарындашлықы болмас ерді... (Хамар деген Хорезм шахының анасы Тұрқан хатынның ағайыны еді, оны Үргеніштің әкімі етіп қойды... Екеуінің бір-біріне ешқандай туыстығы жоқ еді...) [2, 64].

«Тауарихта» қарындаш сөзі туғма сөзімен де қатар қолданылып, әрі «туысқан», әрі «қарындас» мағынасын береді, мыс.: Чингиз хан ның улуғ хатуны Бөрте фужин алар ның қарындашы ерді... Анлар туғмаларын му'аййан қылды лар... (Шыңғыс ханның бәйбішесі Бөрте фужин олардың қарындасы еді... Олар ағайындарын таныстырды...) $[2,166]$. 
«Шыңғыснамада» қарындаш сөзі «туысқан, ағайын» мағынасында қолданылған, мысалы: Қарындашымыз ханны нечүк көрдің уә не түрлік кіші тұрұр... (Хан туысқанымызды қалай көрдің, қандай кісі екен?) [3, 128]. Сол сияқты «Түркі Шежіресіндегі» сіңлі сөзінің ол кездегі мағынасы қазіргіден өзгеше, бұл сөз әйел адамдардың бір-біріне қатынасын ғана білдірмей, бір туған адамдардың жасы кішісін білдірген, мыс.: Әбулхайыр ханның хатұны Ғабдол Латиф мырзаның сіңлісі еркен дүр... (Әбілқайыр ханның әйелі Ғабдол Латиф мырзаның қарындасы екен...) $[2,81]$.

Тон сөзі шежіреде жалпы киім атауын білдірсе, қазір оның бір түрінің, яғни «қой терісінен жасалған жылы сырт киім» мағынасын білдіреді, мыс.: Мысалы: Ол махаллада кефін табмадылар тоны бірлән көмділер... Менің жаным күйгенде өзкелерінің тонының етегі күймес... (Ол кезде кебін таппады, киімімен көмді... Менің жаным күйгенде өзгелердің киімінің (тонының) етегі күймес...) $[2,73]$.

«Шыңғыснамада» тон сөзі жалпы киім атауын білдіреді, мыс.: ...елчіні алыб қайтдылар, тәқы ат тон беріб ұзатдылар... (..елшіні қайтып, ат-киім беріп шығарып салды...) [3, 128]. Тон сөзі ескі қыпшақ ескерткіштерінде «теріден жасалған киім» мағынасын береді, демек, қазіргі қазақ тілі мен ескі қазақ тіліндегі бұл сөздің мағынасы бірдей [11]. Мұндай мағынасы өзгерген сөздердің қатарында күлүк «атақты, атышулы», емкек «бейнет», көңүл «жүрек», еш «жолдас, дос», есір «мас», әуез «дауы» және т.б. жатқызуға болады. Тағы бір топ сөздердің шежіреде кездесетін тұлғасы біраз өзгеріске ұшырағанымен, мағынасы қазіргі тілімізде сақталып қалған. Мәселен, қазіргі қазақ тіліндегі «ағаш» сөзі шежіреде йығач тұлғасында, қазіргі «мұрын» деген сөзіміз бұрұн түрінде, «тауық» сөзі тақұқ формасында кездеседі, мыс.: Бір шағал бір қырғауылны алды йығач бірлән шағалны ұрдұм... Оң йакда алтұн тақұқ беркіткен қырық құлач йығачны тіктүрді... Сені Бестам хакіміне алыб барұр тақы бұрнұң құлақыңны кестүрүр...(Бір шағал (шибөрі) бір қырғауылды алды, мен шағалды ағашпен ұрдым... Оң жақта алтын тауық ұстайтын (аулайтын) қырық құлаш ағаш тіктірді... (Сені Бестам әкіміне алып барып, мұрның мен құлағыңды кестірер.) $[2,64]$.

Әбілғазы, Қадырғали және Өтеміс қажы өз шығармаларында тек қана көне түркі тілін пайдаланбағаны белгілі. Сөз жоқ, олар өздері өмір сүрген кезеңдердегі түркі халықтары қолданған тілді, яғни сол тұстағы түркі сөздерін, араб және парсы тілдерінен енген (кірме) сөздерді де пайдаланады.

«Шыңғыснама», «Әділ сұлтан» эпикалық жыры, «Тауарих» және «Түркі Шежіресі» лексикасының негізі қыпшақ тілі лексикасы болғандықтан, ол сөздердің көпшілігі қазіргі қазақ тілі сөздерімен бірдей тұлғада, бір мағынада келіп жататынын байқау қиын емес. Әсіресе, қазақ халқының ертедегі тұрмысына, салт-дәстүрлеріне қатысты сөздер мен сөз тіркестерінің жазба ескерткіштердегі қолданылған түрі мен бүгінгі тіліміздегі тұлғасы да, мағынасы да бірдей түсіп жатады, мыс. «Түркі Шежіресінде»: ...hәм кішінің бір сүйері өлген болса ұғлы қызы уа йа аға інісі аңа ұхшатұб үйүнде бір қуырчақны йасаб қойады... Бір кішіні йіберділер барча кеткен еллердін сүйінчі тілекіл теб ол кіші әуелі найман халқына барды анлар бір қара қашға ат сүйінчі берділер... Оң хан ның хатұны Бөрте қочын ның йеңечесі ердіұғлан бір йашға йетті ерсе Қара хан елге сауын салды уа тақы үлкен той қылды... (...бір кісінің сүйгені, ұл-қызы немесе аға-інісі өлген болса, оған ұқсатып үйінде бір куыршақ жасап қояды... «Барған барлық елдерден сүйінші сұра» деп бір кісіні жіберді. Ол кісі алдымен найман халқына барды, олар сүйіншіге бір қара қасқа ат берді... Оң ханның әйелі Бөрте қочынның жеңгесі еді [...] ұлы (баласы) бір жасқа келгенде Қара хан елге жария етіп (айтып), үлкен той жасады...) [2, 66].

Әрине жазба ескерткіштердегі түркі сөздерінің барлық тұлғалары қазақ тіліне тән деуге болмайды. Олардың бірқатары фонетикалық тұлғалануы жағынан қазіргі қазақ тіліне алшақтайды. Мысалы, қазіргі қазақ тілінде $y, \breve{u}, \underline{\text { }}$ үнді дауыссыздармен қолданылатын сөздер «Тауарихта» $\boldsymbol{\varepsilon}, \boldsymbol{z}$ дыбыстарымен берілген: йағмур «жаңбыр», тигер «тиер», йағы «жақ», тағ «тау», туғды «туды», йығыб «жиып», төгүрек «төңірек» және т.б. Кейбір тұлғаларда z дыбысы сөз соңында сақталған: сарығ «сары», улуғ «ұлы», қатығ «қатты» және т.б. Дегенмен, бұл тұлғалардың қыпшақтық түрі де кездеседі, мыс.: Тоғум хан ның оғуллары тоғуз сарығ... Йағмур айындан хақның фарманы бірлә йағар, ол сәбәбдін барча халққа әділің тигер йағмур мисаллік... (Тоғум ханның тоғыз сары ұлдары... Жаңбыр айында Алланың бұйрығымен сенің де барша халыққа әділдігің жаңбыр секілді тиер...) [3,141-165].

Кейбір сөздер сыртқы тұлғасы жағынан да морфологиялық құрылымы жағынан да қазақ тілінің нормасына сай түспейді: артуқсы болды «артық болды», бағнақ «бағыну, бағыныш», булғақ «аласапыран», қайусы «қайсысы», қатла «рет», ошал, ошбу «осы» [4,372], сандуқ «табыт» 
және т.б. Сонымен қатар кейбір сөздердің түбірі бір болғанмен, қазақ тіліне құрамы жағынан сай келмейді, мыс.: отқаз «малды отқа жіберу», ханла «хан көтеру», көпәл «көбею» және т.б.

«Жамиғат-Тауарих» тілінде XII-XIV ғасырлардағы оғыз-қыпшақ ескерткіштері болып саналатын «Құтадгу Біліг», «Хосроу мен Шырын», Рабғузидің «Қысал-анбия» сияқты шығармаларда кездесетін көне тұлғалар жоқ деуге болады, мысалы, изи «ие», қоз «қой», азақ «аяқ», қазғу «қайғы» деген лексемалардағы д//3 элементі мұнда жоқ. Сондай-ақ осы жазба ескерткіштердегі ажун «әлем, дүние», асығ «пайда», ал «айла», еш «дос», овуш «тайпа», йалавач «елші» сөздері «Тауарихта» кездеспейді. «Жамиғат-Тауарих» XVI ғасырдың соңында жазылғандықтан, көптеген сөздердің мағыналары тарылып, көнеріп, қазіргі тілімізде қолданылу аясынан шығып қалған. Қадырғали би де өз тұсындағы түркі жазба дәстүрін ана тіліне жуықтата пайдаланған. Қазіргі кезеңде жоғарыда көрсетілген сөздердің ұғымдары түркінің қазақтық, татарлық, өзбектік деген сияқты жергілікті тілдерінде жеке-жеке тұрақталып, не түркі сөздерімен «елші, ру», немесе араб-парсы сөздерімен «дос, әлем, пайда, айла, тайпа» берілетін болған.

XV-XVII ғасырлардағы жазба ескерткіштер тілінде араб, парсы тілдерінен енген кірме сөздері көп кездеседі. Өйткені араб тілінен түркі тілдеріне сөздердің ену процесі VIII ғасырлардан бастап, Моңғол шабуылы дәуіріне дейін де, сол кездің өзінде де, одан кейінгі кезеңде де әр түрлі себептермен және жолдармен болып тұрғаны мәлім. Орта ғасырлардағы түркі жазба ескерткіштерінің барлығында да өзге тілдік қабатты араб, парсы сөздері құрайды.

Тәжік, түрікмен, өзбек, қарақалпақ және қазақ даласында діни орталықтар мен медреселер салынып, ғылым салалары оқытыла басталды. Сонымен қатар мәдени және саяси қарым-қатынастар ұлғайды. Жергілікті халық өкілдерінен әртүрлі саладағы ғылым, мәдениет және әдебиет қайраткерлері шыға бастады. Ол қайраткерлердің көпшілігі өз шығармаларын араб тілінде жазды немесе араб сөздерін молынан қолданды. XI-XII ғасырлардағы жазба ескерткіштерінің тілін зерттеген Г.Құлназарова салыстырмалы түрде сол ғасырлардағы жазба ескерткіштері мен қазіргі қазақ тіліне ортақ араб сөздерінің тұлғалық, мағыналық, мазмұндық жағынан ашып көрсеткен [12, 144] болатын.

XV-XVII ғғ. жазба ескерткіштердегі парсы тілінен енген сөздерге келсек, олар түркі тілдеріне әртүрлі жолдар арқылы енді. Олардың негізгілері төмендегідей:

1. Түркі халықтарының көп жылдар бойы тәжік және парсы халықтарымен көршілес отырып, тікелей қарым-қатынас жасауы арқылы;

2. Көзі ашық білімпаз адамдар жазба әдебиет үлгілері арқылы, сондай-ақ, әртүрлі мәдени байланыстар арқылы енді.

Міне, осындай түрлі жайттардың бәрі араб, парсы тілдерінен түркі тілдеріне көптеген сөздердің енуіне жағдай жасады.

Жазба ескерткіштер ішіндегі Әбілғазы еңбегі XVII ғасырдағы Хиуа тұрғындарының сөйлеу тілінің негізінде жазылды деп есептеледі. Автор «араб, парсы тілдерінен бір де бір сөз қоспадым» дегеніне қарамастан, онда бірсыпыра араб, парсы сөздері кездеседі. Әрине, Әбілғазы сол тұстағы халықтың сөйлеу тілінде кең қолданылатын араб, парсы сөздерін пайдаланбауы мүмкін де емес еді. Сондықтан, шежіре лексикасының едәуір бөлігін араб, парсы сөздері құрайды. Ғалым Б.Әбілқасымов өз кітабында шежіредегі араб тілінен енген сөздерді қазіргі қазақ тіліне қатысы жағынан оларды үш топқа бөліп қарайды:

1) Шежіредегі беретін мағынасы мен тұлғасы қазіргі қазақ тілінде сол күйінде сақталған сөздер;

2) Мағынасында немесе тұлғасында кейбір өзгерістерге ұшыраған күйінде кездесетін сөздер;

3) Қазіргі қазақ тілінде қолданылмайтын сөздер.

Бірінші топқа жататын сөздер өте көп және олар кейін де сөз болатын тақырыптық топтардың барлығын да қамтиды. Мұның себебі, араб тілін енгізуге тырысушылар оны «Қасиетті Құран» тілі ретінде уағыздап, мүмкіндігінше оның бұзылмауына көп күш жұмсаған. Бұл топқа жатқызуға болатын: hөнер «өнер», әулед «әулет», маджилис «мәжіліс», ғадалат «әділет», ықылым «ықылым», жамагат «жамағат, көпшілік, жұрт», хамыр «қамыр», насихат «үгіт, насихат» және т.б. сөздерді атауға болады. Бірнеше мысал келтірейік: Хан хұқім қылды ол жамағатқа қарлық тесүнлер теб... Үч һөнер берген тұрұр... Ол тофрақны хамыр қылыб адамның суретіні йасаб... Хасан хажы Сықанаққа барыб халыққа насихат айтыб тұрұр... (Хан жарлық қылды: «ол жамағатқа (жұртқа) қарлұқ десін» деп... Үш өнер берген еді... Ол топырақты қамыр қылып адам кейпін (суретін) жасап... Хасан қажы Сығанаққа барып, халыққа насихат айтты...) [2, 68]. ...Барча хикаяты падшаһларның дүнийа иклимда муассир һәр бірісі бір уалайат да ерділер... (Патшалардың барлық оқиғалары әлемге белгілі, әр қайсысы бір-бір аймақта еді...) [3, 143]. 
Екінші топтағы сөздер де аз емес. Бұл арада біз олардың тұлғасындағы кейбір орфографиямен байланысты өзгерістерді есепке алмай, көбіне көп мағынасында болған өзгерістер негізге алынды. Мәселен, «Түркі Шежіресінде» афтаб сөзі «күннің көзі» мағынасында қолданылған, мыс.: Афтаб екі найза бойы чықғанда йау келді...Түнлікден үйнің ічіне түшкен афтабдай йарық... (Күн екі найза бойы шыққанда жау келді... Түндіктен үйдің ішіне түскен күннің көзіндей жарық...) [2, 68].

Ал қазір қазақ тілінде «аптап» сөзі «ыссылық, ыссы леп (жел)» мағынасын береді, «алғашқы күннің көзі» мағынасы тарылып қолданылу аясынан шыққан. Сол сияқты шежіредегі емкек «еңбек» сөзінің қазіргі тілімізде тұлғалық жағынан кейбір өзгерістерге ұшырап, мағыналық жағынан жаңарғаны байқалады, мыс.: Оразлымыз кұтұлұр емкекліміз тұтұлғаймыз... (Оразлымыз құтылар, бейнетқорлар тұтылар...) деген сөйлемдегі емкек сөзі қазіргі «бейнет, бейнетқор» мағынасын білдіреді. Бұл сөйлем қазіргі қазақ тілінде мәтел түрінің «Айран ішкен құтылар, шелек жалаған тұтылар» варианты көптеп қолданылады. Осы емкек сөзінен туындаған қазіргі «еңбек» сөзінің мағынасы шежіредегіден мүлдем басқаша жаңа мағынаға ие болды. Қазіргі әдеби тілімізде «ылаж» сөзі бар, бірақ ол қарама-қарсы мағынада қолданылғанда, «Шежіредегідей» парсы тілінің би префиксі арқылы жасалмайды, түркі тілі қосымшасы -сыз жұрнағы қосылу арқылы (ылажсыз) жасалады. Ал «Шежіредегі» формасы билаж. Мысалы: Мұндағылар көб Хасанқұли хан аз чықыб ұрұшқу дек куаты йоқ билаж болды... (Мұндағылар көп еді, Хасанқұли хан аз болып шығып, ұрысатындай күш-куаты жоқ болып, ылажсыз қалды...) [2, 69].

Қазіргі қазақ тіліндегі «нәрсе» сөзі «Түркі Шежіресінде» барлық жағдайда нәмерсе түрінде қолданылған, мыс.: Айтдылар һәм нәмерсе ешітіб ердіңіз барчасы раст... (Айтты: «естіген барлық нәрсе рас болатын...») [2, 69].

Үшінші топ сөздері де өте көп. Әрине, шежіренің жазылған кезеңінде бұл сөздер жергілікті халық тілінде кең қолданылған, мағынасы әркімге барынша түсінікті сөздер болуы керек, кейін қазіргі тілімізде көп қолданылмағандықтан, жұрттың бірі түсінсе, бірі түсінбейтін сөздерге айналған. Бірсыпыра түркі тілдерінде бұл сөздердің бірқатары кеңінен қолданылады. Мұндай сөздерге хәмла «жүкті», зағифа «әйел», фарағат «бейбіт, тыныш», нәубет «кезек», абадан «өркендеген», хәста «ауру», һәмиша «үнемі», пиада «жаяу», кәдхұда «үй, ел иесі», мекер «амалайла», бинаһайат «шексіз», инғам «сыйлық», мұхтасар «айқын, анық» және т.б. жатады, мыс.: Оң хан ата Шыңғыз хан ұғлы болұб фарағат олтұрұб ерділәр... Хәстам ұзаққа тартды... Баһар болғандын соң пиада келе тұрұр... Хатұнұм хәмла ерді туғұрды... Суның йақасында бірнече зағифалар кір йуар тұрұрлар. Анлар келібнәубет бірлән олтұрұр нәубет бірлән ұкларлар ерділәр... Бу ел һәмиша Шыңғыз хан бірлән йау ерділәр... Ләфазы мұхтасар болса һәм мәһнісі мұхтасар ермес тұрұр... (Оң хан ата Шыңғыс ханның ұлы болып, тыныш отыр еді... Ауруым ұзаққа созылды... Көктем болған соң жаяу келеді... Әйелім жүкті еді, босанды... Судың жағасында бірнеше әйел кір жуатын еді... Олар келіп кезекпен отырып, кезекпен ұйықтайтын еді... Бұл ел Шыңғыс ханмен үнемі жау болатын... Сөзі анық болғанмен, мәні анық емес...) [2].

Ғалым Б.Әбілқасымов «Түркі Шежіресінде» кездесетін парсы сөздерін де қазіргі қазақ тіліне қатысты тұрғысынан жіктеп, қазақ тілінде ешбір өзгеріссіз қолданылатын, кейбір фонетикалық, мағыналық өзгерістерге ұшыраған және қазақ тілінде қазір қолданылмайтын сөздер ретінде 3 топқа бөліп қарауға болатындығын айтады: Бірінші топқа пұл, гүл, жануар, құдай, зергер, ұста, сарай, сауда, дост, барабар, бекер, дарваза, қағаз, керней, пешене, шерменде тәрізді сөздерді жатқызуға болады. Бұл сөздердің не мағынасында немесе тұлғасында «Шежіреде» қолданылуы мен қазіргі қолданылуы ешқандай айырмашылық байқалмайды, мыс.: Керуен кіріб чықмақ үчүн бір екі даруаза йері қойұб аңа темүрден даруаза қойдылар... Ол тоқұз йүз ғұмыр табыб жанат сарайыға кетдідостларының күлгенін душманларының йығлағанын көрүб... Өзүмні уа мұнча елімні уа халқымны уа екі ұғұлұмны шерменде қылыб мұндағ намағқұл ішімні һәр кез қылұрмын му... (Керуеннің кіріп-шығуы үшін бір-екі жерден дарбазаға (қақпаға) орын дайындап, темірден дарбаза қойды... Ол тоғыз жүз жыл өмір сүріп, жәннат сарайына кетті достарының күлгенін, дұшпандарының жылағанын көріп... Өзімді, осынша елімді, халқымды және екі ұлымды шерменде қылып, орындалмаған істерімді әркез жүзеге асыра аламын ба?) [2].

Екінші топқа «Түркі Шежіресінде» қолданылуы мен қазіргісінің арасында я фонетикалық, я тұлғалық, я мағыналық жағынан кейбір айырмашылық байқалатын сөздерді жатқызамыз. Оған мысалға мынадай сөздерді алуға болады: тараж «шешу», зынжыр «шынжыр», азар «қайғы», hүмүр «өмір», дарахт «терек», жуфт «жұп», бәндә «пенде» және т.б. Бәндә сөзі «Ясауи хикметтерінде» көбінесе «құдайдың құлы» мағынасында келеді екен. Оның жалпы «адам баласы», «пенде», «қызметші» деген мағыналары сирек [3, 77] көрінеді.Мағыналық жағынан да кейбір өзгеріске ұшыраған сөздер бар. Мәселен, парсының леген сөзі «Шежіреде» қол жуатын ыдыс, 
біздіңше «шылапшын» мағынасында қолданылған, ал қазіргі тілімізде әр жерде әр түрлі, бірде «самауыр астына қоятын жайпақ ыдыс», бірде «поднос» мағынасында, бірде «жайпақ табақ» мағынасында қолданылады. Сол сияқты шежіредегі дүкен сөзі мен қазіргі «магазин» мағынасындағы «дүкен» бір емес.

Үшінші топқа қазіргі тілімізде өте сирек қолданатын, шежіреде жиі кездесетін мына сөздерді атауға болады: асан «жеңіл», паришан «қамқөңіл», хаста «ауру», һәмиша «үнемі», дил «жүрек», гушт «ет», жеван «жігіт», каһ «бірде» және т.б.

- Хастем ұзаққа тартды көңілімде айтдым мен өле қалсам айтылмай қалұр... Бу ел һәмиша Шыңғыз хан бірлән йау ерділер... (Ауруым ұзаққа созылды, көңілімде айттым: «мен өле қалсам, айтылмай қалады...» Бұл ел үнемі Шыңғыс ханмен жау еді...) [2].

Шежіреде кездесетін парсы сөздері өмірдің барлық салаларын қамтиды. Солардың ішінде көбірек кездесетін саласы - сауда-саттық, үй құралдары және діни ұғымды білдіретін лексемалар. Діни ұғымды білдіретін сөздер, көп жағдайда араб тілінде де кездеседі, о баста екі тілдің қайсысының төл сөзі екенін айыру өте қиын $[2,70]$.

«Жамиғат-Тауарих» тілінің лексикалық қазынасында бір мағынадағы сөздің көне-жаңа, қыпшақтық-оғыздық, түркілік-арабтық, түркілік-парсылық, арабтық-парсылық түрлері ретіне қарай бірінің орнына бірі қолданыла беретін сөздер кездеседі. Бұл жарыспалылықтың кейде тіпті ешқандай стильдік не өзге себептері де жоқ болып келуі мүмкін. Алайда кейде бір мағынада алынған сөзді оның екінші түрімен түсіндіріп отыру әрекеті де байқалады. Мұндай лексикалық жарыспалылық - Қадырғали еңбегінде ғана емес, жалпы ортағасырлық түркі ескерткіштерінде де кездеседі. Бұл, бір жағынан әлі жеке-жеке ұлттық тілдер болып қалыптасып бітпеген ортағасырлық түркі жазба тілдерінің лексикалық нормасы тұрақталмағандығын танытса, екінші жағынан, орта ғасырдағы түркі жазба дүниесінің араб және парсы әдебиетімен тығыз байланысты болғандығын көрсетеді. Үшіншіден, көне түркі Орхон-Енисей жазбаларының тілі мен ерте ортағасырлардан (XIXII ғғ.) келе жатқан шығыстүркістандық (көне ұйғыр) жазба әдеби дәстүрінің әсері әлі де болғандығы байқалады.

«Жамиғат-Тауарихта» қолданылған араб сөздерінің көбі дерексіз ұғым атаулары болып табылады. Олардың басым көпшілігі түркі тілдерінің бір қатарына еніп, бүгінге дейін қолданылуда: «дәулет, бақыт, байлық, мемлекет», «негіз, түбір», «мағына», «әдет» және т.б. Халқның дәулеті падша бірлә тұрұр... (Халықтың дәулеті патшасымен...) [6, 141]. Қадырғали би араб сөздеріне түркінің -лық жұрнағын жалғап дерексіз ұғым атауын жасау тәсілін кеңінен пайдаланған, мыс.: мисал лік, адл лік, иззат лық, хурмат лік және т.б. Бір мысал: ...ол себебдін барча халыққа әділің тигер йағмур мисал лік. (...сол себептен барша халыққа сенің әділдігің жаңбыр сияқты тиеді.) [6, 141]. Сондай-ақ араб сөздері күрделі етістік жасайтын компонент ретінде қолданылған. Негізгі компонент араб сөздері, көмекші компоненті түркі тілдерінің қыл-, ет-, бол- сияқты етістіктері болып келетін күрделі қимыл атауларының көбі осы жазба ескерткіште қолданылған, мыс.: ғалиб бол «жеңу», есір ет «тұтқындау», құл қыл «құл қылу», жам бол «жиналу», ихтийат қыл «қорғау», дафн қыл «өлікті жерлеу» және т.б. Бірер мысал: ....сансыз хан оғлы сұлтанларны есір етіп, өзіне құл қылдұрды... (...бірнеше хан ұлдары сұлтандарды тұтқындап, өздеріне құл қылды...) [6, 140].

А.Ысқақовтың пікірінше, қыл-, ет-, бол- көмекші етістіктері әрі жетекші, әрі көмекші қызметін атқарады. Үшеуінің мағыналарында да, түрлену жүйелерінде де, функцияларында да ортақ сипаттар болумен қатар, бір-бірінен ерекшеленетін өзгешеліктері де бар. Бірақ бол етістігі өзінше бір басқалау да, ет, қыл көмекшілері өзара бірыңғайлау. Дегенмен, бұлардың қай-қайсысы болсын есімдермен тіркесе қойып, құранды етістік жасауға аса бейім тұрады және сондай тіркесте өте жиі ұшырайды. Осы ерекшеліктерінен болу керек, әдетте, олардың жетекшіліктерінен гөрі, көмекшілік қызметтері басымырақ көрінеді [9, 277].

Араб сөздерінің етістіктегі мұндай активтігі түркі жазба дәстүріне байланысты, шежіре сияқты тарихи шығарманы өз заманындағы жазба әдеби тілдің нормасына сай болуы - көзі ашық түркілер араб, парсы тілдерін жақсы білгендіктен, жазба ескерткіштер тілінде араб, парсы сөздерін молынан қолдануына қарағанда және мәтінді оқып түсіну үшін айтарлықтай тосқауыл болмаған сияқты. «Жамиғат-Тауарихтың» бөгде тілдік лексика қабатының екінші тобы - парсы сөздері. Бұл шежіре Рашид ад-Диннің парсы тіліндегі «Жами'ат-Тауарихынан» еркін аударма болғандықтан, парсы сөздері өте көп кездеседі. Парсы сөздерінің көбі есім сөздер болып келеді, мыс.: надан, намус, рәнж, арзу, худай, нәсл, лафз, фәрзанд сөздері түркі тілдеріне алуан түрлі жолдармен ертеде еніп, Қадырғали заманында қалыпты элементтерге айналған сөздер деп тануға болады. Өйткені бұл сөздер қазіргі түркі тілдерінің көбінде, тек жазба дәстүрінде емес, халықтың сөйлеу тіліне еніп сіңісіп кеткен сөздер. Бұл сөздер қазіргі қазақ тілінде түпнұсқа тұлғасында сақталған: 
фарзанд «перзент», намус «намыс», лафз «лебіз», панаһ «пана», гүнаһ «күнә» және т.б. Мысалы: Не бу лафз соң заманада анларға моғол деп чықты... (осы лебізден (сөзден) кейін оларға моңғол деп айтты...) [3, 147]. Сонымен қатар Қадырғали парсы тіліндегі тіркестерді өзгертпей сол күйінде пайдаланады, мыс.: асл ләшкер «әскердің негізі», лафз моғол «моңғол тілі» ...лафз моғол йер соңуча кечтілер...(...моңғол тілі жер-жерге тарай бастады...) [3, 147], тахт Қазан «Қазан хандығы» осы секілді парсы изафеті тіркестерін де қолданған, мыс.: мыңар Жади нойан «Жади ноянның мыңдары», хиса екінчі оғлы Чағатай ханның «Чағатай ханның екінші ұлының үлесі» және т.б. Араб сөздері сияқты парсы сөздері де түркі көмекші етістіктерімен келіп, күрделі етістік тұлғаларын жасайды, мыс.: қабул қыл «қабыл қылу», забун қыл «әлсірету», бәнде қыл «тұтқындау, фарман қыл «бұйыру», хуш кел «қош келу» және т.б. ...уа ол қыз насихатыны қабул қылмады... (...ол қыз оның насихат-сөзін қабыл қылмады...) $[3,150]$. Осылайша Қадырғалидің «Жамиғат-Тауарих» атты жазба ескерткіші тілінде араб, парсы сөздерінің едәуір мол қолданылғанын айта аламыз [7, 77].

Өтеміс қажының «Шыңғыснамасында» қолданылған араб сөздерінің басым көпшілігі қазіргі қазақ тіліне еніп, бүгінге дейін қолданылуда: «ахуал», «тарап», «ақыл», «уақыт» және т.б. Сондайақ, араб сөздері күрделі етістік жасайтын компонент ретінде де қолданылған. Көбінесе негізгі компонент араб сөздері, көмекші компоненті түркі тілдерінің қыл-, бол- сияқты етістіктері болып келетін күрделі қимыл атауларының көбі осы шығармада қолданылған, мыс.: фәтһ қылды «жаулап алды», вәфәт болды «опат болды, өлді» және т.б. Мысалы: ...атдын йықылыб бойны сыныб вәфәт болды... (...аттан жығылып, мойны сынып опат болды...) [3, 141]. Негізгі компонент араб сөздері, көмекші компоненті түркі тілдерінің қыл-, бол- сияқты етістіктері болып келетін күрделі іс-қимыл атаулары «Әділ сұлтан» эпикалық жырында ғафл болды, хор болдым «өкініште қалды, қор болдым» және т.б. қолданылған, мысалы: ...құл болдым қамалаған көп жаманға хор болдым... (...құл болдым, қаумалаған көп жаманға қор болдым...) $[1,58]$. Кейбір сөздер қазіргі түркі тілдерінің көбінде, тек жазба дәстүрінде емес, халықтың сөйлеу тіліне еніп сіңісіп кеткен сөздер. Бұл сөздер қазіргі қазақ тілінде түпнұсқа тұлғасында сақталған кейбір әулие, қадір, сұлтан, шиғир «өлең» және т.б. сөздер бар. Мысалы: ...әділ сұлтан жауға түсіп қалған соң шиғир илен айтқан сөзлері... (...әділ сұлтан жаудың қолына түскен соң өлеңмен айтқан сөздері...) $[1,58]$.

Араб сөздерінің етістіктегі мұндай активтігі түркі жазба дәстүріне байланысты, шежіре сияқты тарихи шығарманы өз заманындағы жазба тілдің нормасына сай болуы - автордың міндеті. Орта ғасырлардағы сауатты түркілер араб, парсы тілдерін жақсы білетін болғандықтан, жазба ескерткіш тілінде араб, парсы сөздерін молынан қолдануына қарағанда, мәтінді оқып түсіну үшін айтарлықтай тосқауыл болмаған. Қазақ зиялылары тілімізге араб, парсы сөздерінің енуіне қарсы болғандығы белгілі. Мәселен, Ы.Алтынсарин сөздік жазғанда араб, парсы тілдерінен енген кірме сөздерді пайдалануға қарсы болғандығы [9, 33] байқалады. Е.Букин сөздігіндегі асхана, дәмхана, жаһаннама секілді атаулар Ы.Алтынсарин еңбегінде кездеспейді.

Сонымен XV-XVII ғасырлардағы ескі қазақ жазба тілінің лексикалық сипатын қысқаша былайша көрсетуге болады: сөздік қазынаның негізі қыпшақтық (қазақтық), ішінара оғыз сөздері мен көне ұйғыр элементтері қолданылса, ол - жазба тіл дәстүрінің жалғастылық принципіне қарай болған құбылыс, ал дәстүр жалғастылығы ортағасырлық түркі жазба тілдерінің барлығына тән заңдылықтардың бірі болды. Араб және парсы тілдерінен алып қолданылған лексикалық қабат мол болды, олардың бір тобы халық тіліне енген кірме сөздер болса, екінші тобын көпшілік қолданысында жоқ, бірақ сол кезеңдегі мұсылманша сауатты оқырмандар үшін түсінікті болатын сөздер құрайды. Бұл да ортағасырлық түркі жазба дүниелеріне тән лексикалық норма болып табылады. Осы екі ерекшелік жазба ескерткіштердің мәтінінде лексикалық жарыспалылықтың пайда болуына әсер етті. Бұл заңдылықтардан қазақ жазба тілі де тысқары қалмады.

\section{Әдебиеттер тізімі:}

1. Исин А.И. «Әділ сұлтан эпикалық жыры»: -Алматы, 2001. -120 б.

2. Әбілқасымов Б. Әбілғазы ханның Түркі Шежіресі және оның тілі: -Алматы, 2001. -243 б.

3. Утемиш-хаджи «Чингизнаме»:-Алматы, 1992.-397 б.

4. Өміралиев Қ. XV-XIX ғасырлардағы қазақ поэзиясының тілі:-Алматы, 1976. -318 б.

5. Сыздыкова Р.Г. Язык Жами'ат-Тауарих Жалайри: -Алма-Ата, 1989. -242 с.

6. Құлназарова Г. XI-XII ғ. әдеби ескерткіштердегі араб элементтері: фил. ғыл. канд. дисс: Алматы, 1997. -123 б.

7. Сыздықова Р. Ясауи «Хикметтерінің» тілі:-Алматы, 2004. -894 б.

8. Ысқақов А. Қазіргі қазақ тілі (Морфология): -Алматы, 1974. -408 б.

9. Малбақов М.М. Қазақ сөздіктері: -Алматы, 1995. -162 б. 


\section{References:}

1. Isin A.I. «Әdil słltan ерikalyқ zhyry»:-Almaty, 2001. -120 b.

2. Obilқasymov B. Әbilғazy khannyң Tүrki Shezhiresi zhəne onyң tili:-Almaty, 2001. -243 b.

3. Utemish-khadzhi «Chingizname»:-Almaty, 1992. -397 b.

4. Omiraliev K. KhV-KhIKh ғasyrlardaғу қаzақ роеziiasynyң tili:-Almaty, 1976. -318 b.

5. Syzdykova R.G. Iazyk Zhami'at-Tauarikh Zhalairi:-Alma-Ata, 1989. -242 s.

6. Kylnazarova G. KhI-KhII ғ. ədebi eskertkishterdegi arab elementteri: fil. ғyl. kand. diss: -Almaty, 1997. -123 b.

7. Syzdуқоva R. Iasaui «Khikmetteriniң» tili:-Almaty, 2004. -894 b.

8. Үқақоv А. Қаzirgi қаzақ tili (Morfologiia): -Almaty, 1974. -408 b.

9. Malbaқоv M.M. Қазақ sezdikteri:-Almaty, 1995. -162 b. 